\title{
Tunneled right atrial two-stage cannulation in aortic surgery via ministernotomy
}

\author{
Tamer Türk@, Ufuk Aydın (D, Mesut Engin * (iD and Yusuf Ata (D)
}

To the Editor:

We have read with great interest the article of Sanad et al. [1] entitled Minimally invasive aortic valve replacement with central cannulation: a cost-benefit analysis in a developing country. First of all, we congratulate the authors for their important contribution to the literature. However, we would like to make some contribution to this topic.

Aortic surgery has been performed with median sternotomy for years. After the description of partial sternotomy by Gundry et al. [2] in 1998, upper partial sternotomy ( $\mathrm{J}$ or reverse $\mathrm{T}$ ) is frequently performed in aortic surgery. Unfortunately, this surgical technique requires particular surgical equipment which has an additional cost. In the absence of these equipment, some technical difficulties may occur in the surgical procedure. These equipment can also be not cost-effective. Costeffectiveness can be an important issue especially for developing countries. We also perform minimally invasive aortic root surgery in our center with standard surgical instruments via partial sternotomy. As known, if root enlargement is required in aortic valve surgery, exposure of the aortic root becomes a very important issue [3]. In minimally invasive cardiac surgery procedures, cannulation may also be performed via the peripheral vessels; on the other hand, completing the entire surgical procedure from a single incision has more satisfying clinical results [4].

\footnotetext{
*Correspondence: mesut_kvc_cor@hotmail.com

Department, of Cardiovasculer Surgery, Bursa Yuksek Ihtisas Training and Research Hospital, University of Health Sciences, Mimar Sinan Town, Emniyet Street, Yıldırım, Bursa, Turkey
}

We perform a new venous cannulation technique in our clinic. Also, our technique was presented as a poster (Poster-244, page 215 in poster book) at the 15th Congress of the Turkish Society of Cardiovascular Surgery, October 26-29, 2018, Antalya, Turkey [5]. In this technique, a ministernotomy (extending to the 3rd or 4th intercostal space) was performed after the skin incision. After pericardial incision, central aortic cannulation from the ascending aorta was provided. A flat (low body profile) two-stage venous cannula (Fig. 1A) was inserted through the right atrium's auricula. A 1-cm skin incision was made under the areola (fifth or sixth intercostal space). After the opening of the right pleura, the venous cannula was externalized from the chest by a surgical clamp which is pulling of the distal end of the cannula (Fig. 1B). With this method, pulling out the venous cannula from the thorax wall prevented the narrowing of the surgical field. Also, as the right atrial appendix was retracted, the aortic root exploration was achieved better (Fig. 1C). The incision made for the venous cannula in the chest wall was also used for postoperative tube thoracostomy.

During this technique, subcutaneous fat tissues can enter into the venous cannula. Therefore, washing the cannula with saline is needed after we pass the cannula out. However, since the cannula is in our direct view range, we can intervene all tissue contamination easily.

Another new technique in minimally invasive aortic surgery was described by Pfeiffer et al. in 2015. In this technique, after ministernotomy, a 29-Fr Optiflow venous cannula (Sorin Group, Saluggia, Italy) was placed through a purse suture placed in the superior vena cava by retracting the ascending aorta to the left. The authors, who applied this technique with J sternotomy to 78 patients in a period of 2 years, stated that peripheral 


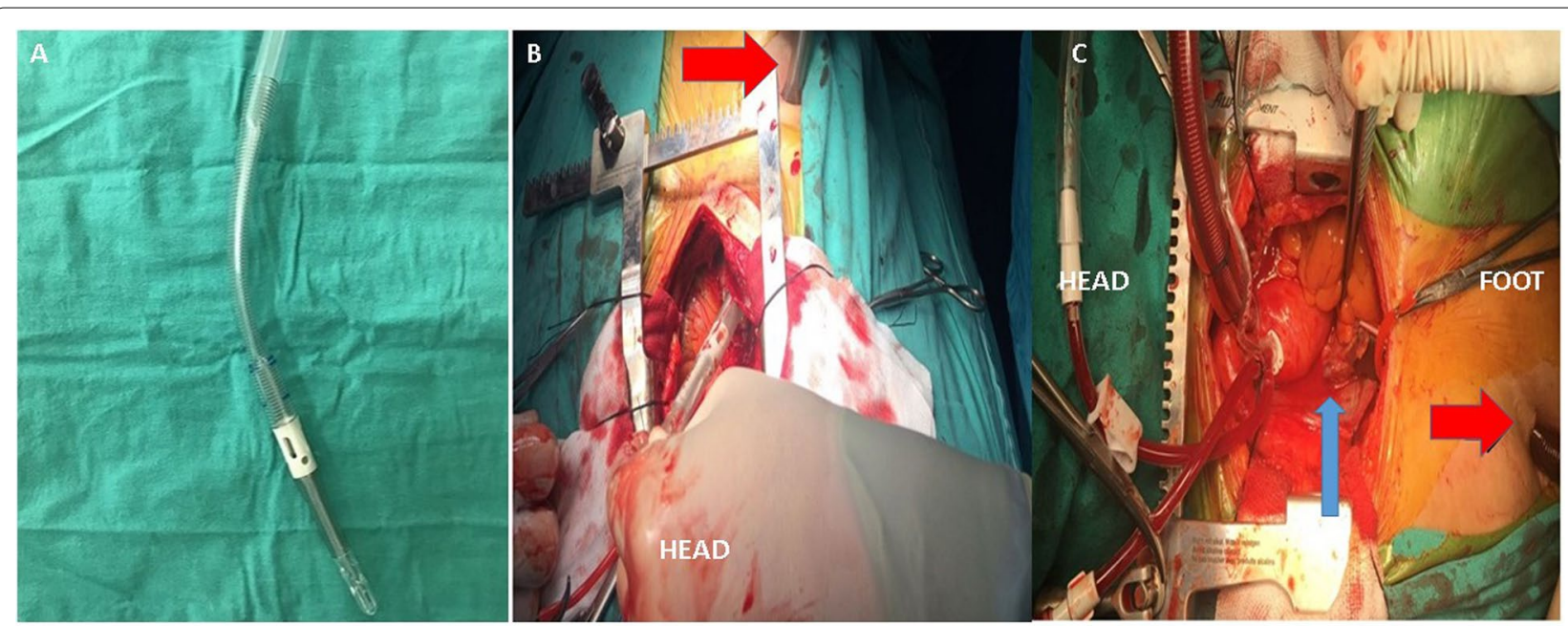

Fig. 1 A Medtronic MC2 ${ }^{\mathrm{TM}}$ two-stage venous cannula (flat body or low profile body). B Venous cannula externalized from the chest. C The right atrial appendix was retracted; the aortic root exploration was achieved better (blue arrow). The red arrows show the exit point of the venous cannula from the right thoracic wall

venous cannulation was required in only one patient [6]. Likewise, Kandakure et al. have described some direct cannulation methods in minimally invasive cardiac surgery in a wide variety of surgeries ranging from congenital surgery to adult surgery in early 2020. They have applied aortic valve replacement to $10 \%$ of the patients (total 140 patients) and inserted the venous cannula in the surgical area within a standard manner [7]. Our technique allows the aortic root expansion procedures, and a thorax tube can be inserted through the same skin incision for the right thoracostomy tube.

Aortic surgery with partial sternotomy is a safe and effective strategy; however, this requires special surgical equipment. Thanks to our technique, with standard surgical equipment, these interventions with partial sternotomy can be successfully performed.

\section{Acknowledgements \\ None}

\section{Authors' contributions}

Hypothesis generation: TT. Concept/design: TT, UA, and ME. Data collection and processing: ME, UA and, YA. Analysis and interpretation: TT, UA, ME, and YA. Literature search: UA and ME. Drafting of the article:TT, UA, ME, and YA. Critical revision of the article:TT, UA, ME, and YA. All authors have read and approved the final manuscript.

\section{Funding}

None.

\section{Availability of data and materials}

Data sharing is not applicable to this letter article.

\section{Declarations}

Ethics approval and consent to participate Not applicable.

\section{Consent for publication}

Written informed consent was obtained from the patient for the image.

\section{Competing interests}

The authors declare that they have no competing interests.

Received: 8 June 2021 Accepted: 22 July 2021

Published online: 11 August 2021

\section{References}

1. Sanad M, Beshir H (2020) Minimally invasive aortic valve replacement with central cannulation: a cost-benefit analysis in a developing country. Cardiothorac Surg 28:9

2. Gundry SR, Shattuck OH, Razzouk AJ, del Rio MJ, Sardari FF, Bailey LL (1998) Facile minimally invasive cardiac surgery via ministernotomy. Ann Thorac Surg 65(4):1100-1104

3. Rocha RV, Manlhiot C, Feindel CM, Yau TM, Mueller B, David TE et al (2018) Surgical enlargement of the aortic root does not increase the operative risk of aortic valve replacement. Circulation 137(15):1585-1594

4. Ata EC, Erkanli K, Ulukan MÖ, Yıldız Y, Türkoglu H, Paslı S (2020) Peripheral vs. central cannulation in cardiac reoperations: technical considerations and outcomes. Br J Cardiovasc Surg 35(4):420-426

5. Conference paper as poster (Poster no: PS-244, page 215 in poster book) at the 15th Congress of the Turkish Society of Cardiovascular Surgery, October 26-29, 2018, Antalya, Turkey. https://tgkdc.dergisi.org/uploads/ pdf/pdf_TGKDC_2748.pdf

6. Pfeiffer $\bar{S}$, Fischlein T, Vogt F, Santarpino G (2015) Superior vena cava cannulation in aortic valve surgery: an alternative strategy for a hemisternotomy approach. Interact Cardiovasc Thorac Surg 20(6):863-865

7. Kandakure PR, Batra M, Garre S, Banovath SN, Shaikh F, Pani K (2020) Direct cannulation in minimally invasive cardiac surgery with limited resources. Ann Thorac Surg 109(2):512-516

\section{Publisher's Note}

Springer Nature remains neutral with regard to jurisdictional claims in published maps and institutional affiliations. 